\title{
TURNER SYNDROME WITH ISOCHROMOSOME Xq AND FAMILIAL RECIPROCAL TRANSLOCATION $\mathrm{t}(4 ; 16)(\mathrm{p} 15.2 ; \mathrm{p} 13.1)$
}

\author{
Cetin $\mathrm{Z}^{1}$, Mendilcioglu $\mathrm{I}^{2}$, Yakut $\mathrm{S}^{1}$, Berker-Karauzum $\mathrm{S}^{1, *}$, Karaman $\mathrm{B}^{3}$, Luleci $\mathrm{G}^{1}$
}

\begin{abstract}
* Corresponding Author: Sibel Berker-Karauzum, Department of Medical Biology and Genetics, Faculty of Medicine, Akdeniz University, Antalya, Turkey; Tel.: +90-242-249-69-70; Fax: + 90-242-227-44-82/227-44-95; E-mail: sibelkarauzum@akdeniz.edu.tr
\end{abstract}

\section{ABSTRACT}

We present here a 16-year-old Turner syndrome patient with a complex karyotype that includes a maternally-inherited balanced translocation between chromosomes 4 and 16 and mosaicism of the isochromosome Xq10. Her karyotype was 45,X,t $(4 ; 16)$ (p15.2;p13.1)[9]/46,X,i(X) (q10),t(4;16)(p15.2;p13.1) [91]. The karyotype of her father was normal, whereas that of her mother had the same balanced translocation and numerical abnormalities of chromosome $\mathrm{X}$ and was designated as $45, \mathrm{X}, \mathrm{t}(4 ; 16)(\mathrm{p} 15.2 ; \mathrm{p} 13.1)$ [2]/ 46,XX,t(4;16)(p15.2;p13.1)[93]/47,XXX,t(4;16) (p15.2; p13.1)[5]. The two siblings of the patient also had the same reciprocal translocation. We consider this to be the first such patient with an inherited reciprocal translocation and structural abnormality of the X chromosome (isochromosome $\mathrm{Xq}$ ).

Keywords: Turner syndrome; Reciprocal translocation; Cytogenetics; Isochromosome Xq

\footnotetext{
Department of Medical Biology and Genetics, Faculty of Medicine, Akdeniz University, Antalya, Turkey

2 Department of Obstetrics and Gynaecology, Faculty of Medicine, Akdeniz University, Antalya, Turkey

3 Prenatal Diagnosis Centre, Faculty of Medicine, Istanbul University, Istanbul, Turkey
}

\section{INTRODUCTION}

Turner syndrome is a common genetic disorder affecting approximately 50 in 100,000 live-born females in Caucasian populations [1]. Considerable heterogeneity of phenotypic features are associated with Turner syndrome, the most consistent being short stature, gonadal dysgenesis, webbed neck, lymphedema, cubitus valgus. Cardiovascular malformations, bone and thyroid disorders, renal and liver dysfunctions may also be observed. The karyotype in approximately $50 \%$ of Turner syndrome patients is non mosaic monosomy $\mathrm{X}$ $(45, X)$, followed in frequency by non mosaic isochromosomes of the chromosome $\mathrm{X}$ long arm $[46, \mathrm{X}, \mathrm{i}(\mathrm{X})$ (q10)] and mosaicism of monosomy $\mathrm{X}$ and isochromosome Xq [2]. In addition, $\mathrm{Xp}$ or Xq deletions and ring (X) chromosomes may also be observed during cytogenetic analyses [3]. Coexistance of an familially transmitted autosomal translocation and Turner syndrome karyotype is a rare phenomenon and only a few cases were reported in the literature [4-10]. We here present a 16-year-old Turner syndrome patient who had an isochromosome of the long arm of chromosome $\mathrm{X}$ in a mosaic form and, like her mother, familial reciprocal translocation between chromosomes 4 and 16 . 


\section{CASE REPORT}

The patient was born to non consanguineous phenotypically normal parents and was referred to the Department of Obstetrics and Gynaecology at the Faculty of Medicine, Akdeniz University, Antalya, Turkey, for evaluation of primary amenorrhea when she was 16 years old. Her mother and father were 22 and 32 years old, respectively, at the time of her birth. Their family included a 21-year-old brother and an 18-year-old sister. Another pregnancy had resulted in spontaneous abortion.

The patient was $135 \mathrm{~cm}$ tall and weighed $45 \mathrm{~kg}$. Physical examination showed short stature, undeveloped breasts, and webbed neck. On ultrasound, her ovaries could not be seen and the uterus was hypoplasic. The plasma hormone levels were: luteinizing hormone $29.30 \mathrm{mIU} / \mathrm{mL}(2.40-12.60 \mathrm{mIU} / \mathrm{mL})$; follicle stimulating hormone $74.81 \mathrm{mIU} / \mathrm{mL}(3.50-12.50 \mathrm{mIU} /$ $\mathrm{mL})$; estradiol $15.12 \mathrm{pg} / \mathrm{mL}(24.50-195.00 \mathrm{pg} / \mathrm{mL})$; thyroid stimulating hormone $5.92 \mathrm{uIU} / \mathrm{mL}(0.27-4.20$ $\mathrm{uIU} / \mathrm{mL}$ ). Hematological parameters and plasma mineral values were in normal ranges.

Peripheral blood samples were obtained from the proband, her parents and siblings. Chromosome analyses were performed using GTG banding [11]. A complex karyotype including a balanced translocation between chromosomes 4 and 16 and mosaicism of the isochromosome Xq10 was observed during conventional cytogenetic analyses of the proband (Figure 1a and $1 \mathrm{~b}$ ). Using CBG-banding (C-band by barium hydroxide us-

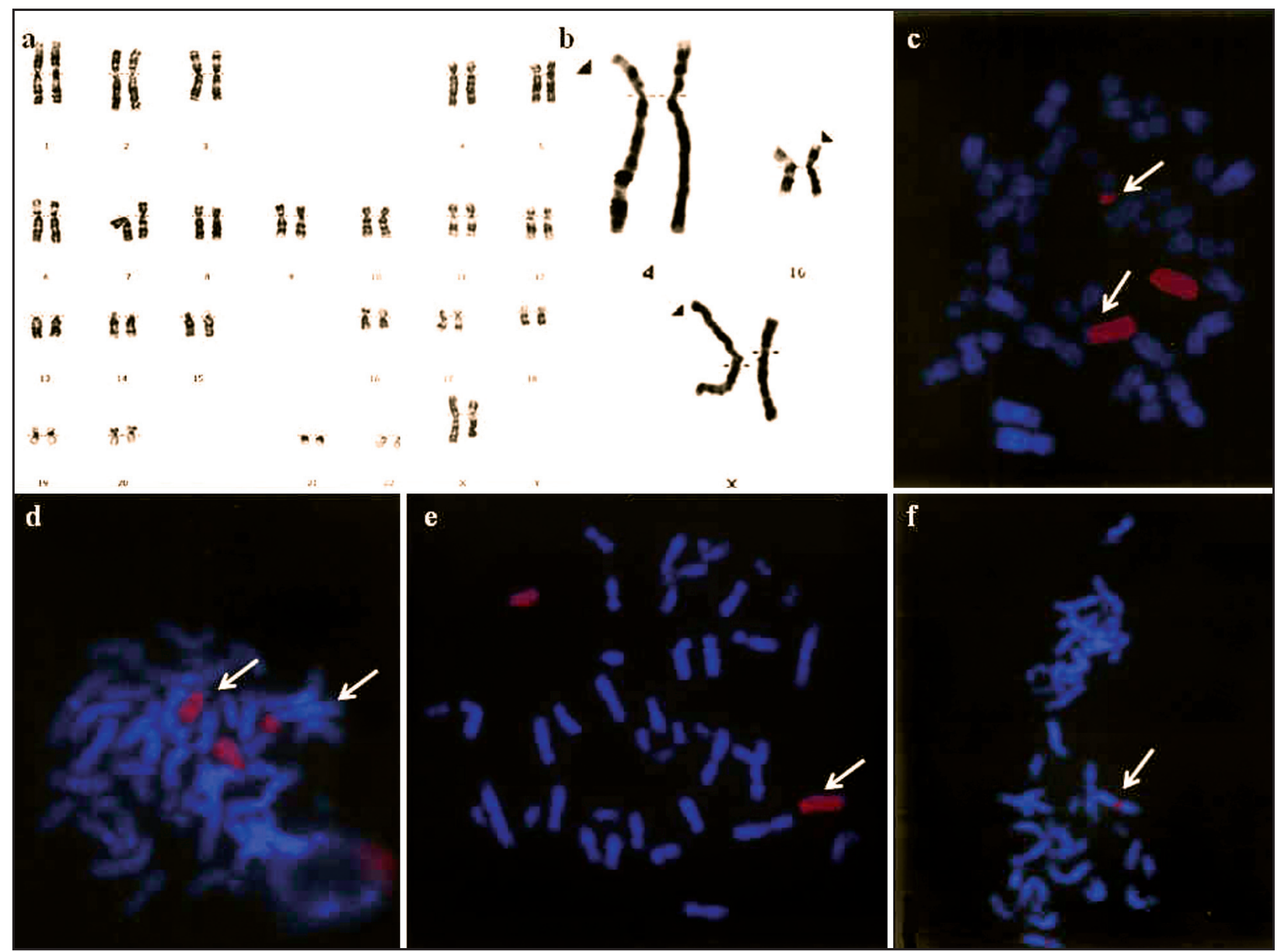

Figure 1. a) Karyotype of the proband showing balanced $\mathrm{t}(4 ; 16)(\mathrm{p} 15.2 ; \mathrm{p} 13.1)$ translocation and isochromosome $(\mathrm{X})(\mathrm{q} 10)$. b) Partial karyotype of the proband showing balanced translocation between chromosomes 4 and 16 and isochromosome (X)(q10). c and d) The FISH analysis results, using whole chromosome painting probes specific for chromosomes 4 and 16, indicating a balanced translocation between chromosomes 4 and 16. e) The FISH analysis results, using whole chromosome painting probe specific for chromosome $\mathrm{X}$, indicating one normal chromosome $\mathrm{X}$ and one isochromosome Xq. f) The FISH analysis results using $\alpha$ satellite DNA probes specific for chromosome X. 
ing Giemsa staining) studies showed one C-band on isochromosome $\mathrm{Xq}$, indicating that isochromosome $\mathrm{X}$ was apparently monocentric. Fluorescent in situ hybridizaton (FISH) studies used whole chromosome painting probes specific to chromosomes 4 and 16 (Vysis Inc, Downers Grove, IL, USA) to confirm the trans-location between these chromosomes (Figure 1c and 1d). The FISH studies, using a probe specific to chromosome $\mathrm{X}$, confirmed the presence of isochromosome Xq10 (Figure 1e). Metaphase plates were evaluated using an $\alpha$ satellite (DXZ1) centromeric probe (Vysis Inc.) specific for chromosome $\mathrm{X}$ to evaluate $\alpha$ satellite DNA on the isochromosome Xq. Two centromeric signals were observed in $91 \%$ of the peripheral blood lymphocytes, one on the normal chromosome $\mathrm{X}$ and the other on the isochromosome $\mathrm{X}$. The FISH signal on isochromosome Xq10 was more intense than that of the normal chromosome X (Figure 1f). The final karyotype of the proband was designated as $45, \mathrm{X}, \mathrm{t}(4 ; 16)(\mathrm{p} 15.2 ; \mathrm{p} 13.1)$ [9]/46,X,i(X)(q10),t(4;16) (p15.2;p13.1)[91].

The father's karyotype was normal, whereas the mother's had the same balanced translocation and numerical abnormalities of the chromosome $\mathrm{X}$ in a mosaic state and was designated as $45, \mathrm{X}, \mathrm{t}(4 ; 16)(\mathrm{p} 15.2 ; \mathrm{p} 13.1)$ [2]/46, XX,t(4;16)(p15.2;p13.1)[93]/47,XXX,t(4;16) (p15.2; p13.1)[5]. The same reciprocal translocation was a observed in both of the proband's siblings; the maternal grandparents were not available for cytogenetic analyses.

\section{DISCUSSION}

The coexistence of a balanced translocation and a chromosome $\mathrm{X}$ abnormality in Turner syndrome patients is rarely reported in the literature [4-10]. Four cases were carriers of a parentally transmitted Robertsonian translocation and had the non mosaic $44, X, t(13 ; 14)(q 10 ; q 10)$ karyotype [4-7]. Of these, three had inherited the translocation from their mothers and one from the father $[4,7]$. No other family members carried the translocation and sex chromosomal abnormality in these reports. There are three Turner syndrome patients with a familial balanced reciprocal translocation and monosomy of the $\mathrm{X}$ chromosome in the literature [8-10]. In these reports ,the reciprocal translocations were $\mathrm{t}(2 ; 22)(\mathrm{q} ? ; \mathrm{q} ?), \mathrm{t}(1 ; 22)(\mathrm{q} 32 ; \mathrm{q} 21)$ and $\mathrm{t}(8: 19)$ (p21:p13), and no other family member was affected by sex chromosome abnormalities in two reports $[9,10]$. However, a boy with true hermaphro- ditism and 46,XX/46,XY mosaicism formed part of the family reported by Anneren et al. [8].

Our Turner syndrome patient had reciprocal translocation and structural abnormality of the X chromosome (isochromosome Xq). The clinical picture of our patient was mild and this finding is concordant with the previous reports indicating that most of the Turner syndrome patients with structural $\mathrm{X}$ chromosome abnormalities had mild phenotypes [12,13]. The numerical chromosome $\mathrm{X}$ abnormalities in low-level mosaic state observed in the mother was not associated with phenotypic abnormalities. However, the spontaneous abortion of the third pregnancy of the mother might be associated with the balanced translocation.

As proposed by James et al. [14], the absence of a 46,XX cell line in our patient could suggest that a post-zygotic mechanism is not likely, unless the errors occurred during the first post-zygotic mitotic cell division. Alternatively, the patient may have been conceived with the karyotype $46, \mathrm{X}, \mathrm{i}(\mathrm{Xq})$ in a non mosaic state and a subsequent loss of the isochromosome from a proportion of cells resulted in the $45, \mathrm{X} / 46, \mathrm{X}, \mathrm{i}(\mathrm{Xq})$ karyotype [14]. There are several proposed mechanisms resulting in formation of isochromosome Xq. Generally, isochromosome $\mathrm{Xq}$ chromosomes are structurally dicentric chromosomes containing proximal Xp material suggesting that the most likely mechanism of formation is chromatid breakage and reunion in proximal Xp [15]. The more intense centromeric $\alpha$ satellite DNA signal on the isochromosome Xq observed in our case suggests that chromatid breakage and reunion in proximal Xp could be acceptable as a mechanism of formation in our case. Previous molecular genetic studies in patients with structural balanced translocations and monosomy $\mathrm{X}$ have excluded a meiotic non disjunction interchromosomal effect [4]. Unfortunately, we could not apply molecular genetic studies to show a possible effect of the maternal balanced translocation on the formation of isochromosome $\mathrm{Xq}$ because the family members were unavailable for further molecular genetic studies.

As a result, in some Turner syndrome patients with structural chromosome $\mathrm{X}$ abnormalities accompanied by the familial transmitted balanced translocation, the carrier parents might have chromosome $\mathrm{X}$ abnormalities in a mosaic state. Therefore, the parental chromosomes should be evaluated to rule out possible low level numerical/structural chromosome $\mathrm{X}$ abnormalities which may be important for the management of further pregnancies. 


\section{ACKNOWLEDGMENTS}

This study was supported by the Akdeniz University Scientific Research Project Management Foundation, Antalya, Turkey.

\section{REFERENCES}

1. Hjerrild BE, Mortensen KH, Gravholt CH. Turner syndrome and clinical treatment. Br Med Bull. 2008; 86(1): 77-93.

2. Doswell BH, Visootsak J, Brady AN, Graham JM Jr. Turner syndrome: an update and review for the primary pediatrician. Clin Pediatr (Phila). 2006; 45(4): 301313.

3. Kesler SR. Turner syndrome. Child Adolesc Psychiatr Clin N Am. 2007; 16(3): 709-722.

4. Da Silva AL, Ferriera de Lima RLL, Ribeiro LA, Moretti-Ferreira D. X monosomy and balanced Robertsonian translocation in a girl with Turner syndrome. Genet Molec Biol. 2006; 29(1): 47-48.

5. Krajinovic M, Ivanovic K, Mestroni L, Diklic V, Nikolis J. Parental origin of the $\mathrm{X}$ chromosome in a patient with a Robertsonian translocation and Turner's syndrome. J Med Genet. 1994; 31(3): 255-256.

6. László J, Bösze P, Gaál M, Tóth A. A case of 44,X streak gonad syndrome combined with familial balanced 13/14 translocation. Acta Med Hung. 1984; 41(4): 223-227.

7. Salamanca F, Buentello L, Sanchez J, Armendares S. A patient with 44 chromosomes. Ann Genet. 1985; 28(2): 130-132.
8. Annerén G, Frykberg T, Gustavson KH. A boy with true hermaphroditism and sex chromosome mosaicism and a fertile woman with Turner mosaicism in a family with a translocation 8p:19p. Clin Genet. 1981; 20(4): 289-295.

9. Kondo I, Hamaguchi H, Matsuura A, Nakajima H, Koyama A, Takita H. A case of Turner's syndrome with familial balanced translocation $\mathrm{t}(1 ; 2)(\mathrm{q} 32 ; \mathrm{q} 21)$ mat. $\mathrm{J}$ Med Genet. 1979; 16(4): 321-323.

10. Lejeune J, Lafourcade J, Salmon C, Turpin R. Familial 2-22 translocation; association with a haplo-X Turner's Syndrome. Ann Genet. 1963; 6(1): 3-8.

11. Benn PA, Perle MA. Chromosome staining and banding techniques. In: Rooney DE, Czepulkowski BH, Eds. Human Cytogenetics: A Practical Approach, Vol. I. Constitutional Analysis. Oxford: IRL Press Ltd. 1992: 91-118.

12. Leppig KA, Disteche CM. Ring $X$ and other structural $\mathrm{X}$ chromosome abnormalities: $\mathrm{X}$ inactivation and phenotype. Semin Reprod Med. 2001; 19(2): 147-157.

13. Ruibal Francisco JL, Sánchez Burón P, Piñero Martinez E, Bueno Lozano G, Reverte Blanc F. Turner's syndrome. Relationship between the karyotypes and malformations and associated diseases in 23 patients. An Esp Pediatr. 1997; 47(2): 167-171.

14. James RS, Dalton P, Gustashaw K, Wolff DJ, Willard HF, Mitchell C, Jacobs PA. Molecular characterization of isochromosomes of Xq. Ann Hum Genet. 1997; 61(Part 6): 485-990.

15. Wolff DJ, Miller AP, van Dyke DL, Schwartz S, Willard HF. Molecular definition of breakpoints associated with human Xq isochromosomes: implications for mechanisms of formation. Am J Hum Genet. 1996; 58(1): 154-160. 